\title{
Evaluation of Rice Germplasm against Bacterial Leaf Streak Disease Reveals Sources of Resistance in African Varieties
}

\author{
Issa Wonni ${ }^{1,2 *}$, Gustave Djedatin ${ }^{3}$, Léonard Ouédraogo $0^{1,2}$ and Valérie Verdier ${ }^{3}$
}

${ }^{1}$ Institut de l'Environnement et de Recherches Agricoles (INERA), 01 BP 910 Bobo Dioulasso, Burkina Faso

${ }^{2}$ Laboratoire Mixte Internationnal, observatoire des agents phytopathogènes en Afrique de l'Ouest, Biosécurité et Biodiversité (LMI Patho-Bios), 01 BP 910 Bobo Dioulasso, Burkina Faso

${ }^{3}$ Institut de Recherche pour le Développement, UMR IPME, IRD-CIRAD-UM2, 911 Avenue Agropolis BP 64501, 34394 Montpellier Cedex 5, France

\begin{abstract}
Bacterial leaf streak caused by Xanthomonas oryzae pv. oryzicola $(X o c)$ is a rice disease emerging in West Africa. Its emergence is correlated with the recent expansion of rice cultivation and the introduction of new rice varieties. Our goal is to identify resistance sources to control BLS in rice. We evaluated six Oryza sativa and two Oryza glaberrima accessions for resistance to bacterial leaf streak under greenhouse conditions. Three week-old plants were inoculated with different $X o c$ strains originated from Mali and the Philippines. Two Oryza sativa accessions (FKR14 and ITA306) show a high level of resistance to African Xoc while are susceptible to the Philippines one. The others accessions tested are susceptible to all Xoc strains tested. We identify new resistance sources to $X$. oryzae pv. oryzicola that could be used by breeders, thus improving yield of rice crops in West Africa.
\end{abstract}

Keywords: Xanthomonas oryzae pv. Oryzicola; Resistance; Rice; Africa

\section{Introduction}

Bacterial leaf streak (BLS) is an important disease of rice and is caused by Xanthomonas oryzae pv. oryzicola (Xoc). Xoc is occuring in the tropical and subtropical areas of Asia, and Australia [1]. In Africa the disease was reported in Madagascar, Senegal and Nigeria in the 1980's [2]. More recently BLS was observed in Mali and Burkina Faso $[3,4]$. Recently increase of BLS disease was observed in Asia and Africa likely due to the planting of susceptible varieties [3-5]. The increase of BLS disease may also be related to climate changes occuring in SubSaharan Africa [6].

BLS develops in the field at any growth stage of rice. Initial symptoms are water-soaked, interveinal streaks along the leaf. Xoc is an intercellular pathogen that enters plants through wounds or by invading open stomata [1]. Xoc multiplies in the substomatal chamber and colonizes the apoplast of the mesophyll cells [7,8]. Xoc oozes from natural openings in strands or strings on the leaf surface and exudates can spread the disease directly from plant to plant by contact, or indirectly via irrigation water and by windblown rain [9]. Xoc is a seedborne and a seed-transmitted pathogen [10]. Yield losses due to this disease depend on the rice variety cultivated and climatic conditions but typically range from 10-20\% [1]. Effective quarantine and deployment of resistant germplasm are key factors to control BLS disease. Accurate detection of Xoc is critical for diagnostic and regulatory purposes. A multiplex PCR assay was developed to simultaneously detect and distinguish the different pathovars of $X$. oryzae infecting rice [11]. The multiplex is currently used to identify Xoc strains in West Africa $[4,12]$.

Planting of resistant cultivars is the most effective method for controlling BLS. However, most rice germplasm cultivated in Asia is susceptible to BLS. Raymundo et al. [13] reported that the African variety Morobereckan (upland japonica) is one of the most resistant to Asian Xoc strains. The wild rice O. meyeriana and O. officinalis showed a high level of resistance to Chinese Xoc strains [14].

Single rice resistant genes have not been found to control BLS resistance and no strategy has been pursued for controlling the disease in Africa so far. Rxo1, a gene from maize, confers resistance to Xoc strains in transgenic rice when the corresponding effector gene avrRxo1 (also named xopAJ) is present in the pathogen [15]. avrRxo1 is present in all the Philippines Xoc strains [10] while absent in most African Xoc strains isolated in 2003 and 2009 [3,4]. More recently it has been shown that a larger number of Xoc strains isolated in Mali and Burkina Faso harbor a functional avrRxo1 [12]; Dao et al. personal communication). According to Han et al. [16], AvrRxo1-ORF1 is adjacent to AvrRxo1ORF2 gene, which was predicted to encode a molecular chaperone of AvrRxo1-ORF1. They found that AvrRxo1-ORF1 contributes to X. oryzae proliferation on rice plants, and strongly suppresses bacterial growth in the absence of AvrRxo1-ORF2.

While Rxo1 may be a useful gene for combatting BLS in Asia, it is not clear yet if that will be the case in West Africa. Also the genetic diversity observed among Xoc strains require to identify an efficient breeding strategy for BLS in Africa [3]. Comparative mapping of BLS resistance to Asian Xoc strains has led to the identification of Quantitative Trait Loci (QTL) [17]. Recently a recessive $R$ gene, bls1, conferring resistance on Xoc was localized to chromosome 6 from a rice line DP3 derived from Oryza rufipogon [18].

Given the severity and extent of BLS epidemics in recent years in West Africa, identifying resistance against Xoc is an important goal for breeding programs. The objective of this study was to evaluate rice varieties for resistance to Xoc strains.

*Corresponding author: Issa Wonni, Institut de l'Environnement et de Recherches Agricoles (INERA), 01 BP 910 Bobo Dioulasso, Burkina Faso, Tel: +22670156832; E-mail:wonniissa@yahoo.fr

Received October 09, 2015; Accepted November 02, 2015; Published November 05, 2015

Citation: Wonni I, Djedatin G, Ouédraogo L, Verdier V (2015) Evaluation of Rice Germplasm against Bacterial Leaf Streak Disease Reveals Sources of Resistance in African Varieties. J Plant Pathol Microb 6: 312. doi:10.4172/2157-7471.1000312

Copyright: (c) 2015 Wonni I, et al. This is an open-access article distributed under the terms of the Creative Commons Attribution License, which permits unrestricted use, distribution, and reproduction in any medium, provided the original author and source are credited. 


\section{Materials and Methods}

\section{Germplasm evaluated}

Six O. sativa. susbp. indica accessions Curinga, FKR14, ITA306, PaDckono, TN1, and IR64; two accessions of O. glaberrima TOG6767 and TOG5672 and the transgenic line Kitaake-Rxo1 were evaluated for resistance to Xoc strains (Table 1). Most of these accessions are grown in West Africa and possess good agronomic characteristics such as drought tolerance and resistance to other diseases. TN1 is known to be susceptible to BLS [19] and was used in this study as a susceptible control. IR64 and ITA306 were identified as highly resistant to African Xanthomonas oryzae pv. oryzae, the causal agent of Bacterial Blight (BLB) while TOG6767 and TOG5672 are moderately resistant [20]. FKR14 is grown in main rice areas in Burkina Faso. Originated from India, FKR14 was introduced in Burkina Faso in 1976 [21]. It is a highly productive, plastic and suitable variety for upland and irrigated rice growing regions. It is sensitive to iron toxicity and susceptible to Rice Yellow Mottle Virus and Bacterial Blight diseases [21,5]. All plants were grown in the greenhouse under controlled conditions at $28^{\circ} \mathrm{C}$, $12 \mathrm{~h} / 12$ day/night with $80 \%$ humidity in IRD Montpellier.

\section{Bacterial strains and plant inoculation}

Three Xoc strains were used in this study (Table 2). Xoc MAI3 (CFBP7326) and MAI10 (CFBP7331) were isolated in Mali in 2003 [3]. Both strains exhibit different virulence level on the rice cultivar Nipponbare and possess different Transcription Activator like (TAL) genes [3,12]. Xoc BLS256 originated from the Philippines was isolated in 1985. Except xopAJ and xopW genes, African Xoc strains share the same type III effectors genes with Xoc strain BLS256 [12]. Additional 50 Xoc strains collected in Mali and Burkina Faso in 2009 representative of the genetic diversity of Xoc in West Africa [12] were tested on the FKR14 variety. All strains were stored in $15 \%$ glycerol at $-80^{\circ} \mathrm{C} . X$. oryzae strains were grown on PSA medium (peptone $10 \mathrm{~g}$, sucrose $10 \mathrm{~g}$, glutamic acid $1 \mathrm{~g}$, agar $8 \mathrm{~g}, \mathrm{pH} 7.0$ ) for $24 \mathrm{~h}$ at $30^{\circ} \mathrm{C}$, then resuspended in sterile water at $0,2 \mathrm{OD}_{600}$ (approximately $10^{8} \mathrm{cfu} \mathrm{ml}^{-1}$ ).

\begin{tabular}{|c|c|c|c|c|}
\hline Accessions & Subspecies & $\begin{array}{c}\text { IRGC accession } \\
\text { number-ID }\end{array}$ & $\begin{array}{c}\boldsymbol{R} \text { gene to } \\
\text { BB or BLS }\end{array}$ & Origin \\
\hline Curinga & indica & - & ND & Brazil \\
\hline FKR14 & indica & - & ND & Burkina Faso \\
\hline IR64 & indica & 66970 & ND & IRRI \\
\hline ITA306 & indica & - & ND & Nigeria \\
\hline PaDcKono & indica & - & ND & Sierra Leone \\
\hline TN1 & indica & 105 & Xa14 & Taiwan \\
\hline TOG 6767 & glaberrima & - & ND & Liberia \\
\hline TOG5672 & glaberrima & & ND & Nigeria \\
\hline Kitaake Rxo1 & Transgenic line & - & $R \times 01$ & IRRI \\
\hline
\end{tabular}

Table 1: Accessions used in this study.

\begin{tabular}{|c|c|c|c|}
\hline Strains & MAl3 & MAl10 & BLS256 \\
\hline Origin & Mali & Mali & Philippines \\
\hline virulence classe & 5 & na & 5 \\
\hline${ }^{\text {axopAJ }}$ & + & - & + \\
\hline${ }^{\text {bxopW }}$ & + & $>$ & + \\
\hline Reference & Wonni et al. [20] & Wonni et al. [20] & Wonni et al. [20] \\
\hline
\end{tabular}

${ }^{a}$ All the $X o c$ strains that are positive for xopAJ induced a hypersensitive response 72 hours after inoculation while the strains that are negative for xopAJ induce watersoaking lesions on Kitaake-Rxo1.

${ }^{b}$ Presence or absence of xopW; > indicates that a DNA arrangement (insertion element) was identified within the xopW gene.

Table 2: Strains used in this study to screen cultivars for resistance to Xoc.
Rice leaves from 3-week-old plants were inoculated by leaf infiltration as described previously [22]. Leaf reactions were observed $72 \mathrm{hr}$ after inoculation (hai), and lesions were measured 12 days after inoculation (dai). At least six infiltrations were done per leaf with two leaves per plant and two to three plants per strain. A scale was established for BLS disease according to the size of the lesion length (LL) induced by Xoc strains: Resistant (R), $0<\mathrm{LL} \leq 1 \mathrm{~mm}$; Moderately Resistant (MR), $1<\mathrm{LL} \leq 10 \mathrm{~mm}$; Moderately Susceptible (MS), $10<\mathrm{LL} \leq$ $30 \mathrm{~mm}$; Susceptible (S), LL $>30 \mathrm{~mm}$. The entire experiment was repeated three times.

\section{Colonization of leaf tissue by Xoc}

Four rice varieties TOG5672, TOG6767, FKR14 and TN1 were selected and further inoculated as described above. Multiplication of Xoc strains was measured in planta at three time points (0,7 and 15 dai). Each leaf was cut into $5 \mathrm{~cm}$ section below and above the leaf-infiltrated area. The leaf pieces were ground in $1 \mathrm{ml}$ of sterile water. Bacterial numbers were assessed in serial dilutions that were spread onto PSA agar plates. The plates were incubated at $28^{\circ} \mathrm{C}$ until single colonies could be counted. The experiment was repeated four times.

\section{Results}

\section{Xoc virulence vary depending on rice variety}

To determine whether Xoc strains vary in their virulence, eight rice varieties were leaf infiltrated with Xoc strains BLS256, MAI3 and MAI10. Xoc BLS256 caused leaf streak symptoms on all varieties (unless KitaakeRxo1) with lesion length varying from 7,6 to 59,5 mm depending the variety (Table 2). Lesion length induced by MAI3 and MAI10 vary from 0 to $30,8 \mathrm{~mm}$.

The reaction induced by Xoc strains varied according to the variety. For example, on varieties TN1, ITA306, Xoc strain BLS256 caused large lesions, while on others (TOG5672, TOG6767) lesions were small (Figure 1). Both strains MAI3 and MAI10 induced very similar lesions on all the varieties tested but one.

While BLS256 induces small and large lesions on FKR14 and ITA306 respectively, MAI3 and MAI10 induced a resistant reaction. On FKR14, a hypersensitive reaction (HR) was observed $48 \mathrm{~h}$ to $72 \mathrm{~h}$ post inoculation with strains MAI3 and MAI10 (Figure 2). FKR14 was then tested with 50 African Xoc with an HR consistently observed (data not shown). Out of eight varieties, two (FRK14 and ITA306) showed a strong resistance response to African Xoc strains. The HR response observed with FKR14, suggests the resistance to be mediated by African Xoc effectors. It is noted that MAI3 and BLS256 harboring xopAJ gene induce HR on Kitaake-Rxo1. ITA306 is susceptible when challenged with strain BLS256. On the opposite, ITA306 is immune to African Xoc strains (Table 3). Variety TN1 is highly susceptible to all Xoc strains tested.

\section{Resistance to BLS is associated with low multiplication of Xoc strains}

Xoc strain BLS256 caused substantial lesions on rice varieties FKR14 and TN1 when compared to MAI3 and MAI10. To determine the effect of plant on bacterial population growth, bacterial numbers were determined in infiltrated leaves.

There was no significant difference in population growth between MAI3 and MAI10 on all varieties tested except Kitaake-Rxo1 (Figure 3). In TOG6767 and TOG5672, no difference in population growth 


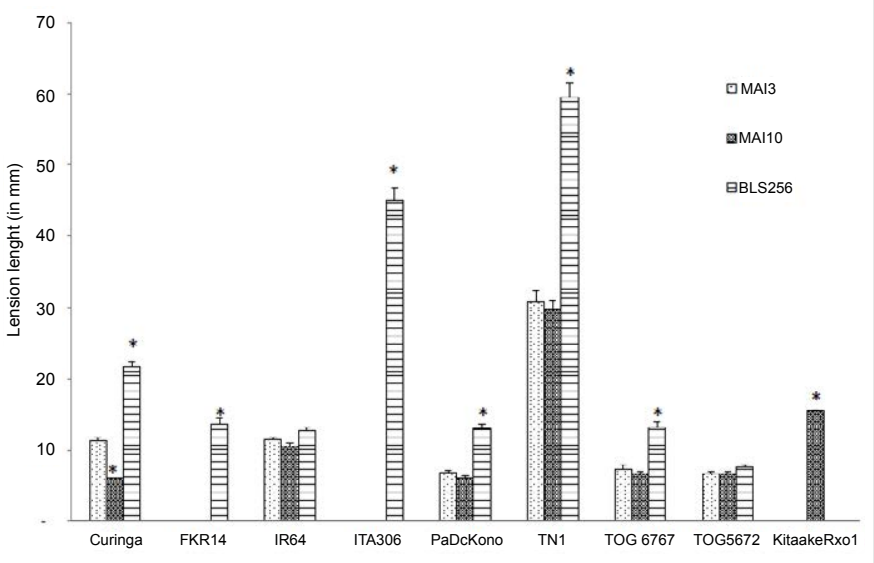

Figure 1: Lengths of lesions caused by $X$. oryzae pv. oryzicola strains BLS256, MAI10 and MAI3 on six rice accessions of $O$. sativa sp. Indica, two accessions of O. glaberrima (TOG6767, TOG5672) and trangnic indica line Kitaake-Rxo1. Lesions were measured 15 days after infiltration. An asterisk denotes a significant difference between BLS256 and African Xoc $\left({ }^{*}, \mathrm{P}<0.05\right)$. The experiment was repeated three times with similar results.

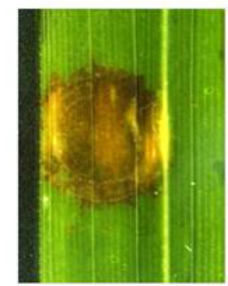

B

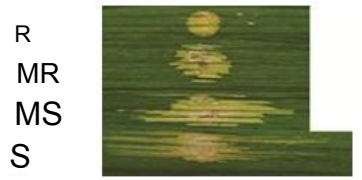

Figure 2: Reactions in leaves of rice accessions at 15 days after infiltration with MAI3, MAI10 and BLS256. Phenotypes were photographed on a light box. (A) Hypersensitive reaction (HR), visible as browning in response to MAI3 and MAI10 on FKR14 leaves; (B) Scale used to assess disease level: Resistant $(R), 0<L L \leq 1 \mathrm{~mm}$; Moderately Resistant (MR), $1<\mathrm{LL} \leq 10 \mathrm{~mm}$; Moderately susceptible (MS), $10<\mathrm{LL} \leq 30 \mathrm{~mm}$; Susceptible (S), LL>30 mm.

was observed between plants infected with BLS256, MAI3 and MAI10. Unlike FRK14 no significant increase of bacterial growth of Xoc strains was observed with MAI3 and MAI10 between 7 and 15 days after inoculation (Figure 3).

On TN1 although Xoc BLS256 induced larger lesions compared to that of MAI3 and MAI10 (Figure 1), there was no significant difference between the population growth of Xoc strains (Figure 3). A significant increase of the bacterial population was observed 15 days after inoculation with all the strains tested (Figure 3).

In FKR14, BLS256 numbers were significantly greater than MAI3 and MAI10 at 7 and 15 days after inoculation. Both African strains were detected at low levels in leaf tissues. Together these results show that bacterial population increases in a susceptible cultivar (TN1) and remains stable in resistant accessions FKR14.

\section{Discussion}

Eight rice accessions were tested for their resistance to African and Asian Xoc strains. Among these, two O. sativa FKR14 and ITA306 show a resistance response when challenged with African Xoc strains while are moderately to highly susceptible to the Philippines strain Xoc BLS256. The reaction induced by African Xoc strains on FKR14 corresponds to a hypersensitive reaction with a dark browning area appearing 48 to $72 \mathrm{~h}$ after inoculation. Resistance and susceptibility to $X o c$ in rice are correlated with quantitative differences in the bacterial population. The hypersensitive reaction is associated with lower levels of bacterial population in leaves when compared to a susceptible reaction.

No single resistance gene to BLS disease has been characterized in rice. The transgenic rice lines with $R x o 1$ gene exhibit an HR symptom when inoculated with Xoc harboring the corresponding effector gene avrRxo1 [3,4]. The HR phenotype observed in African cultivars (FKR14) occurs independently of the presence or absence of the avrRxo1 gene in Xoc strains. This suggests that the resistance observed in FKR14 to African Xoc strains differs from the one induced by Rxo1.

Zhou et al. [23] showed that upon infection with Xoc a larger number of Differentially Regulated Genes (DRG) are expressed in transgenic rice line expressing Rxo1 gene when compared to wild type. We need to characterize genes that are induced in resistant cultivars such as FKR14 upon infection with African Xoc strains.

Also, TOG5672 a glaberrima accession exhibits a moderately resistant reaction correlated with low bacterial numbers when challenged with African and Asian Xoc. To confirm TOG5672 as a broad source of resistance to Xoc, we need to test a larger number of strains.

We identify novel and broad-spectrum resistance sources to contsrol BLS in rice in Africa. Characterization of genes and markers underlying BLS resistance mechanisms will be mandatory for future use in breeding program.

Crossing of FKR14 with TN1 that is highly susceptible to Xoc strains and/or the use of Multi-Parent Advanced Generation InterCross lines (MAGIC) can be achieved to identify markers associated to BLS resistance [24]. Meanwhile, resistance in FKR may be introgressed in others rice accessions by classical breeding to further manage BLS disease in Africa.

\begin{tabular}{|c|c|c|c|c|c|c|}
\hline & \multicolumn{5}{|c|}{ Strains used } \\
\hline & MAI3 & & MAl10 & & BLS256 & \\
\hline Accession & LL + SE & DR & LL+ SE & DR & LL + SE & DR \\
\hline Curinga & $11.3 \pm 0.4$ & MS & 6 & MR & $21.7 \pm 0.8$ & S \\
\hline FKR14 & 0 & $\mathrm{R}$ & 0 & $\mathrm{R}$ & $13.67 \pm 0.9$ & MS \\
\hline IR64 & $11.4 \pm 0.4$ & MS & $10.5 \pm 0.5$ & MS & $12.7 \pm 0.5$ & MS \\
\hline ITA306 & 0 & $\mathrm{R}$ & 0 & $\mathrm{R}$ & $45 \pm 1.8$ & $\mathrm{~S}$ \\
\hline PaDcKono & $6.8 \pm 0.3$ & $\mathrm{MR}$ & $6 \pm 0.4$ & $\mathrm{MR}$ & $13 \pm 0.6$ & $\mathrm{MS}$ \\
\hline TN1 & $30.8 \pm 1.5$ & $\mathrm{~S}$ & $29.71 \pm 1.2$ & $\mathrm{~S}$ & $59.4 \pm 2$ & $\mathrm{~S}$ \\
\hline TOG 6767 & $7.3 \pm 0.5$ & $\mathrm{MR}$ & $6.7 \pm 0.3$ & $\mathrm{MR}$ & $13.2 \pm 0.7$ & $\mathrm{MS}$ \\
\hline TOG5672 & $6.7 \pm 0.2$ & $\mathrm{MR}$ & $6.7 \pm 0.2$ & $\mathrm{MR}$ & $7.6 \pm 0.3$ & $\mathrm{MR}$ \\
\hline Kitaake-Rxo1 & 0 & $\mathrm{R}$ & $15.5 \pm 0.11$ & $\mathrm{MS}$ & 0 & $\mathrm{R}$ \\
\hline
\end{tabular}

LL: Length lesion induces by $X o c$ strains upon infiltration 15 days after inoculation, $\mathrm{P}<0.005$; SD: Standard Deviation, DR: Disease Reaction, Resistant $(\mathrm{R}), 0<\mathrm{LL} \leq$ $1 \mathrm{~mm}$; Moderately Resistant (MR), $1<\mathrm{LL} \leq 10 \mathrm{~mm}$; Moderately susceptible (MS), 10 $<\mathrm{LL} \leq 30 \mathrm{~mm}$; Susceptible (S), LL > 30mm.

Table 3: Length lesion induced by Xoc strains on rice varieties. 
A

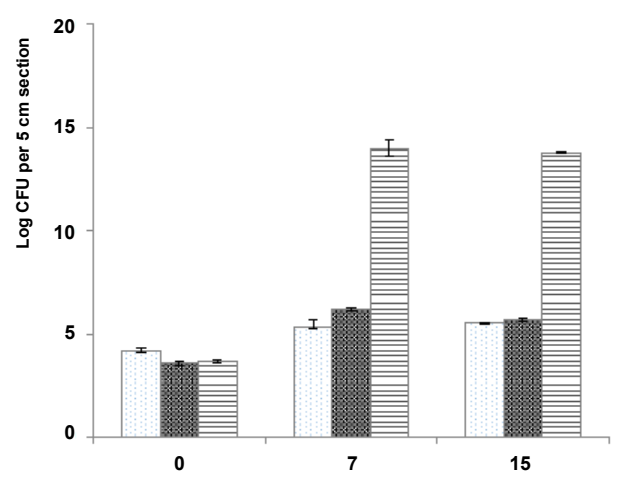

C

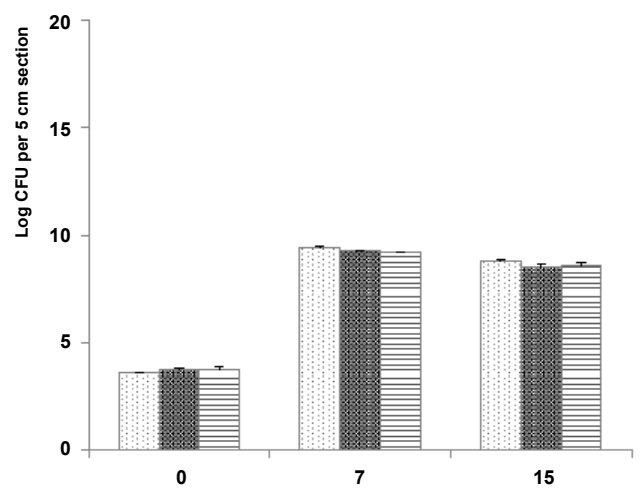

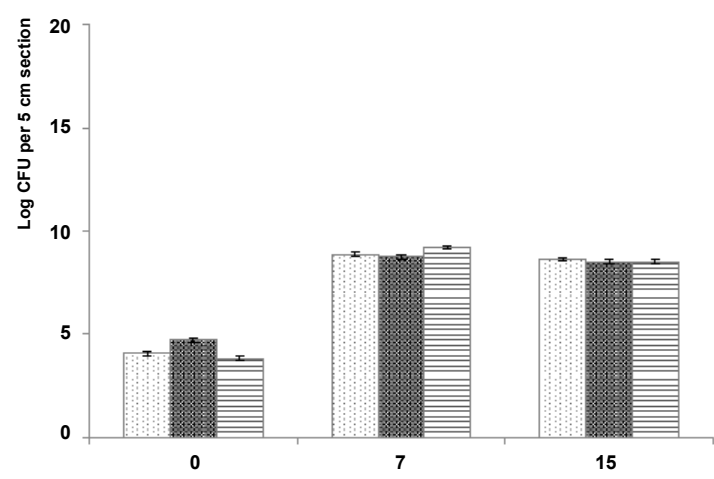

D

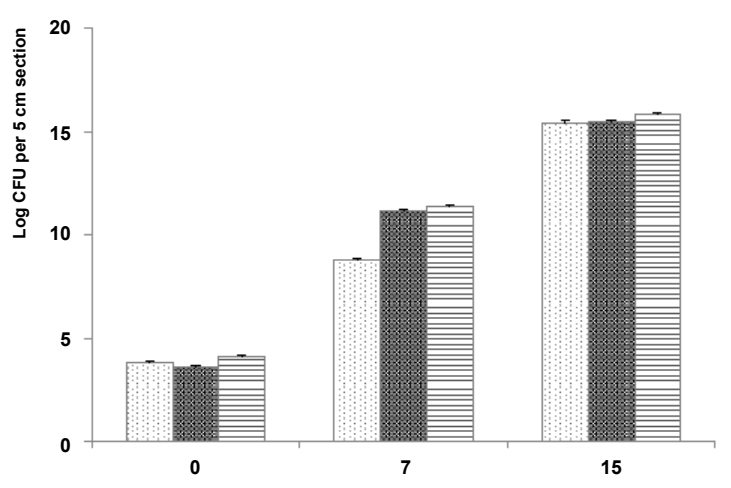

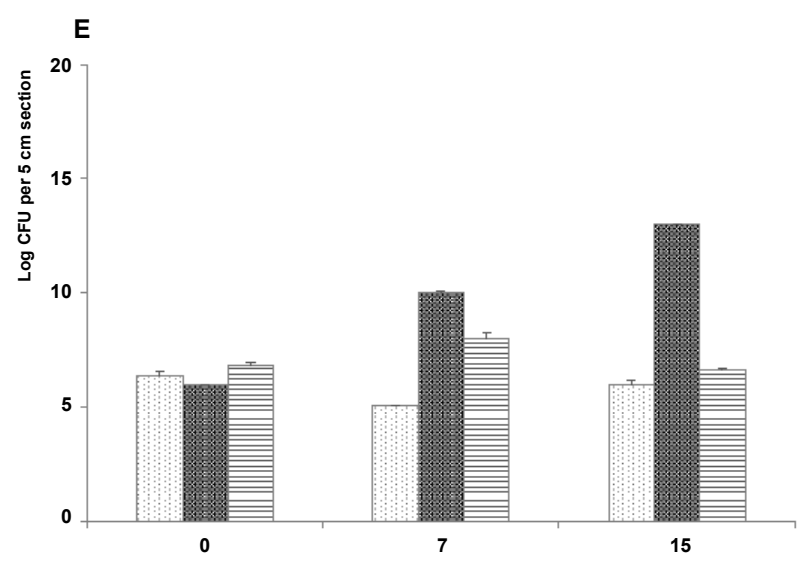

Figure 3: Bacterial growth in 3-week-old leaves of FKR14 (A), TOG5672 (B), TOG6767 (C). TN1 (D) rice accessions and trangenic line Kitaake-Rxo1 (E). Bacterial population was measured in a $5 \mathrm{~cm}$ leaf segment around the infiltration point at 0,7 and 15 days after inoculation with Xoc strains MAI3, MAl10 and BLS256. The experiment was repeated three times. Error bars represent standard error.

\section{Acknowledgements}

I. Wonni is currently supported by an IRD DPF (Direction des Programmes de recherche et de la Formation au Sud) fellowship. This work was partially supported by the INERA (Burkina Faso), IRD UMR RPB, LBMA (Mali), and the International Foundation For Science (IFS) grant awarded to I. Wonni (C/4813-1 and C/4813-2).

\section{References}

1. Ou SH (1985) Rice Diseases. 2nd Ed. Commonwealth Mycological. Instt. Kew. England pp: 247-256.
2. Awoderu VA, Bangura N, John VT (1991) Incidence, distribution and severity of bacterial diseases on rice in West Africa. Trop Pest Manag 37: 113-117.

3. Gonzalez C, Szurek B, Manceau C, Mathieu T, Séré Y, et al. (2007) Molecular and pathotypic characterization of new Xanthomonas oryzae strains from West Africa. Mol Plant Microbe Interact 20: 534-546.

4. Wonni I, Ouedraogo L, Verdier V (2011) First report of bacterial leaf streak caused by Xanthomonas oryzae pv oryzicola on Rice in Burkina Faso. Plant Dis Rep 1: 72. 
Citation: Wonni I, Djedatin G, Ouédraogo L, Verdier V (2015) Evaluation of Rice Germplasm against Bacterial Leaf Streak Disease Reveals Sources of Resistance in African Varieties. J Plant Pathol Microb 6: 312. doi:10.4172/2157-7471.1000312

5. Ouedraogo SL, Somda I, Wonni I, Seré Y (2007) Résistance au flétrissement bactérien de lignés inter- et intraspécifiques de riz de bas fonds en conditions d'infestation artificielles. African Crop Science Journal 15: 191-199.

6. Müller C, Cramer W, Hare WL, Lotze-Campen H (2011) Climate change risks for African agriculture. Proc Natl Acad Sci U S A 108: 4313-4315.

7. Mew TW, Vera Cruz CM (1986) Colonization of host and non-host plants by epiphytic phytopathogenic bacteria. Microbiology of the Phyllosphere. Eds. N.J. Fokkema, J. Van Den Heuvel, New York: Cambridge Univ. P. 269-282.

8. Niño-Liu DO, Ronald PC, Bogdanove AJ (2006) Xanthomonas oryzae pathovars: model pathogens of a model crop. Mol Plant Pathol 7: 303-324.

9. Mew TW, Alvarez AM, Leach JE, Swings J (1993) Focus on bacterial blight of rice. Plant Dis Rep 77: 5-12.

10. Xie GL, Mew TW (1998) A leaf inoculation method for detection of Xanthomonas oryzae pv. oryzicola from rice seed. Plant Dis 82: 1007-1011.

11. Lang JM, Hamilton JP, Diaz MGQ, Van Sluys MA, Burgos MAG, et al. (2010) Genomics-based diagnostic marker development for Xanthomonas oryzae pv. oryzae and X. oryzae pv. oryzicola. Plant Dis 93: 311-319.

12. Wonni I, Cottyn B, Detemmerman L, Dao S, Ouedraogo L, et al. (2014) Analysis of Xanthomonas oryzae pv. oryzicola population in Mali and Burkina Faso reveals a high level of genetic and pathogenic diversity. Phytopathology 104: 520-531.

13. Raymundo AK, Briones AMJ, Ardales EY, Perez MT, Fernandez LC, et al. (1999). Analysis of DNA polymorphism and virulence in Philippine strains of Xanthomonas oryzae pv. oryzicola. Plant Dis 83: 434-440.

14. Peng SQ, Wei ZS, Mao CX (1982) Identification of multi resistance of $O$. meyeriana, $O$. officinalis and $O$. sativa f. spantanea growing in Yunan Province. Acta Phytopathologica Sinica 12: 58-60.

15. Zhao B, Lin X, Poland J, Trick H, Leach J, et al. (2005) A maize resistance gene functions against bacterial streak disease in rice. Proc Natl Acad Sci U S A 102: $15383-15388$

16. Han Q, Zhou C, Wu S, Liu Y, Triplett L, et al. (2015) Crystal Structure of Xanthomonas AvrRxo1-ORF1, a Type III Effector with a Polynucleotide Kinase Domain, and Its Interactor AvrRxo1-ORF2. Structure 23: 1900-1909.

17. Wang C, Wen G, Lin X, Liu X, Zhang D (2008) Identification and fine mapping of the new bacterial blight resistance gene, Xa31(t), in rice. Eur J Plant Pathol.

18. He WA, Huang DH, Li RB, Qiu YF, Song JD, et al. (2012) Identification of a resistance gene bls1 to bacterial leaf streak in wild rice Oryza rufipogon Griff. J Integr Agr 11: 962-969.

19. Verdier V, Vera Cruz C, Leach JE (2012) Controlling rice bacterial blight in Africa: needs and prospects. J Biotechnol 159: 320-328.

20. Djedatin G, Ndjiondjop MN, Mathieu T, Vera Cruz CM, Sanni A, et al. (2011) Evaluation of African cultivated rice Oryza glaberrima for resistance to bacterial blight. Plant Dis 95: 441-447.

21. INERA (2000) Fiches descriptive des variéties de riz. INERA, Burkina Faso.

22. Reimers PJ, Leach JE (1991) Race-specific resistance to Xanthomonas oryzae pv. oryzae conferred by bacterial blight resistance gene Xa10 in rice (Oryza sativa) involves accumulation of a lignin-like substance in host tissues. Physiological and Molecular Plant Pathology 38: 39-55.

23. Zhou YL, Xu MR, Zhao MF, Xie XW, Zhu LH, et al. (2010) Genome-wide gene responses in a transgenic rice line carrying the maize resistance gene $R \times 01$ to the rice bacterial streak pathogen, Xanthomonas oryzae pv. oryzicola. BMC Genomics 11: 78.

24. Zhao B, Ardales EY, Raymundo A, Bai J, Trick HN, et al. (2004) The avrRxo1 gene from the rice pathogen Xanthomonas oryzae pv. oryzicola confers a nonhost defense reaction on maize with resistance gene Rxo1. Mol Plant Microbe Interact 17: 771-779. 